\title{
Updated OpenStudio Small and Medium Office Prototype Models
}

\author{
Piljae $\operatorname{Im}^{1}$, Joshua R New ${ }^{1}$, Yeonjin Bae ${ }^{1}$ \\ ${ }^{1}$ Oak Ridge National Laboratory, Oak Ridge, United States of America
}

\begin{abstract}
The U.S. Department of Energy supports the development of commercial building energy codes and standards by participating in industry review, update processes, and providing technical analyses to support both published model codes and potential changes. In support of ANSI/ASHRAE/IES Standard 90.1 and International Energy Conservation Code, 16 commercial prototype building models were developed that cover $80 \%$ of the commercial building floor area in the United States for new construction, including both commercial buildings and mid- to high-rise residential buildings, across all U.S. climate zones. Of these, the small, medium, and large office buildings take about $12 \%$ of total commercial building floor area.

Currently, small, medium, and large office prototype building models have simplified, single space type, while other building types includes more detailed space types. As such, the office prototype could not be easily used to properly assess changes (i.e. measures applied) to difference spaces commonly found in an office. This work has added new space types to the small and medium office, with properties based on several vintages of ASHRAE Standard 90.1 in different climate zones, and compared energy use of these newly-improved models with that of the original models.
\end{abstract}

\section{Introduction/Background}

The U.S. Department of Energy (DOE) supports the development of commercial building energy codes and standards by participating in industry review, update processes, and providing technical analyses to support both published model codes and potential changes. DOE publishes its findings to ensure transparency in its support, and to make its analysis available for both public review and use. In conjunction with this effort, DOE's flagship building energy model (BEM) tools consist of the open-source EnergyPlus simulation engine and OpenStudio. These tools allow a user to modify a building, estimate energy use, and new releases are typically downloaded by over 20,000 users.

As part of DOE's support for ANSI/ASHRAE/IES Standard 90.1 (ANSI/ASHRAE/IES, 2016) and International Energy Conservation Code (IECC) (International Code Council, 2015), researchers at Pacific Northwest National Laboratory (PNNL) apply a suite of prototype buildings covering approximately $80 \%$ of the commercial building floor area (PNNL, 2013; Goel et al., 2014) in the United States for new and existing construction, including mid- to high-rise residential buildings, across all U.S. climate zones. These prototype buildings-derived from DOE's Commercial Reference Building Models (Deru et al., 2011)-cover all Reference Building types (except for supermarkets), and an additional prototype representing high-rise apartment buildings. As Standard 90.1 and IECC are updated every three years, PNNL makes modifications to the commercial prototype building models with extensive input from ASHRAE 90.1 Standing Standards Project Committee (SSPC) members and other building industry experts.

The prototype models include 16 commercial building types in 17 climate locations (across all 8 U.S. climate zones) for recent editions of Standard 90.1 and IECC. The current combination results in an overall set of 2,176 total building models (in EnergyPlus Version 8.0). Small and medium office were selected as the most common types of building, which has simplified space type in current set of prototype building model suites. As such, the small and medium office prototype could not be easily used to properly assess changes (i.e. measures applied) to difference spaces commonly found in a small and medium office. This work has added new space types to the small and medium office, with properties based on Standard 90.1, and compared energy use of this newly-improved models with that of the original models.

While the Prototype Building Models were originally defined as EnergyPlus input files, redefining them as OpenStudio models, which in turn can generate EnergyPlus input files, has several advantages. First, OpenStudio allows measure-based modification of buildings for defining ASHRAE 90.1-compliant baseline models, analysis of retrofit options, cloud-based computation, and reporting of energy-based analysis. OpenStudio also has the ability to write these models to file formats for other simulation engines, including ongoing efforts to write buildings that can run in the Modelica-based "Spawn" program that could potentially start replacing EnergyPlus in 3-5 years. The tradeoff for such flexibility is that EnergyPlus and OpenStudiowritten EnergyPlus files may have slightly different results which require comparison and characterization. 


\section{Use cases}

The authors are part of a multi-lab team working to incorporate a new set of prototype commercial building models developed in collaboration with the ASHRAE Advanced Energy Simulation Working Group, supporting low-energy building design through Standards 90.1 and 189.1. OpenStudio Standards is a collection of Measures and resources that automate the construction of prototype building models (e.g., office, hospital, primary school) as well as the transformations associated with ASHRAE Standard 90.1 Appendix G "Performance Rating Method", a commonly exercised transformation that supports code compliance, LEED certification, and utility incentive calculations. OpenStudio Server allows vendors and users to combine seed models - either prototypical or specific_-with Measures in a large-scale computing environment to quickly and systematically specify and organize large scale analyses such as uncertainty analysis model calibration, design optimization, or stock level measure analysis. The authors outline several of the intended uses that were considered in the definition of the improved small and medium office prototypes:

- $\quad$ Space Types

- The traditional office models did not support the enhanced detail afforded by additional space types (e.g. offices, conference rooms, restrooms). By adding more detail via space types, building energy modelers gain greater specificity over building attributes.

- Measures

- Measures specific to individual space types can more accurately quantify energy, demand, or water savings opportunities.

- HVAC control

- Different space types allow specification of (customizable) occupancy schedules in a way that allows customizable control over HVAC control algorithms. This could include VAV operation with relevant equipment specification and occupancy.

- Demand response

- The growing interest in demand reduction as part of the value proposition for energy efficiency requires more specific details related to occupancy and equipment to provide ranges on the grid services specific equipment may be able to provide.

\section{Methods}

\section{Original small and medium office prototype}

The small office building model is a 1-story building with $511 \mathrm{~m}^{2}(27.7 \mathrm{~m} \times 18.4 \mathrm{~m})$ of conditioned floor area, as shown in Figure 1. The building has four perimeter zones, and one core zone with perimeter zone depth of $5 \mathrm{~m}$. The building has also unconditioned attic space. Window-towall ratio is approximately $24.4 \%$ for South and $19.8 \%$ for the other tree orientations. The window dimensions for all facades is $1.8 \mathrm{~m} \times 1.5 \mathrm{~m}$. The construction of the exterior walls and roof are wood-frame walls, and attic roof with wood joist, respectively. The foundation type is unheated slab-on-grade with $0.2 \mathrm{~m}$ concrete slab poured directly on to the earth. The building HVAC system is air source heat pump systems with gas furnace as back up. The system is constant volume single zone system, which has one unit per occupied thermal zone. The HVAC system capacity is autosized per design day. The building has thermostat setpoint temperature for $23.9 \mathrm{C}$ and $21.1 \mathrm{C}$ for cooling and heating, respectively. The thermostat setback setpoint temperature is $29.4 \mathrm{C}$ and $15.6 \mathrm{C}$ for cooling and heating, respectively

The medium office prototype model is also one of 16 building types for the prototype models. The medium office building model is a 3-story building with $4978.6 \mathrm{~m}^{2}$ $(49.9 \mathrm{~m} \times 33.3 \mathrm{~m})$ of conditioned floor area, as shown in Figure 1. Each floor has four perimeter zones, and one core zone with perimeter zone depth of $4.6 \mathrm{~m}$. Windowto-wall ratio is approximately $33 \%$, and the ribbon windows are evenly distributed along four facades. The height of the window is $1.3 \mathrm{~m}$. The construction of the exterior walls and roof are steel-frame walls, and built-up roof (i.e., roof membrane + roof insulation + metal decking), respectively. The foundation type is unheated slab-on-grade with $0.2 \mathrm{~m}$ concrete slab poured directly on to the earth. The building HVAC system is a packaged DX air conditioning unit with gas furnace, and VAV terminal box with electric reheating coil provides conditioned air to each zone. The building has thermostat setpoint temperatures are the same with the small office prototype building. Further details regarding the small and medium office prototype building model can be found in Building Energy Codes Programs (Building Energy Codes Programs, 2019).

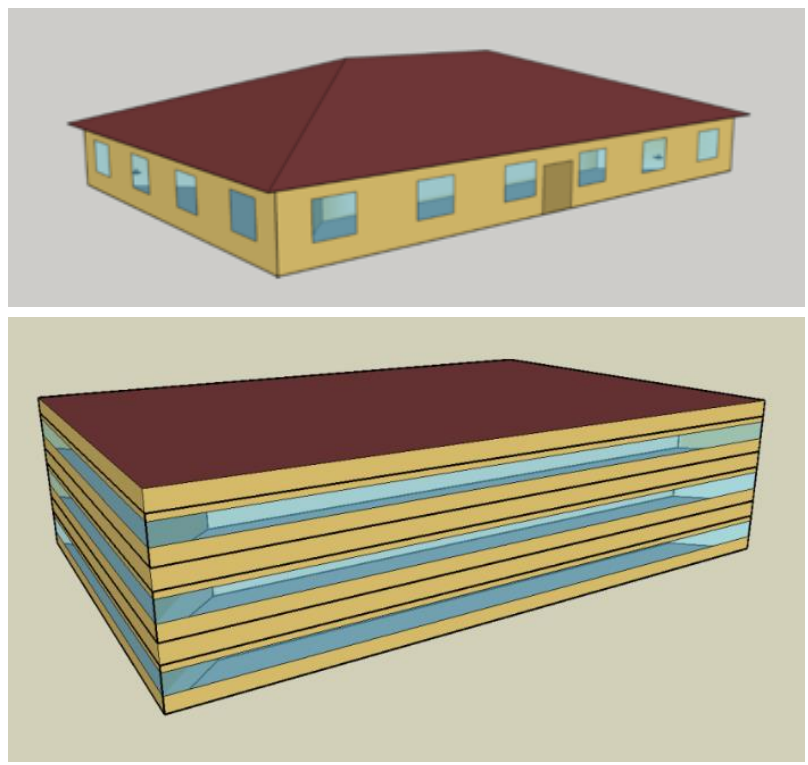

Figure 1: $3 D$ rendering of the original small office (top) and medium office (bottom) prototype building models.

As described earlier, the typical office building contains various space types such as open office, enclosed office, 
conference room, restroom, and corridor, but the existing small and medium office prototype has a uniform space type, which is defined as "office" as shown in Figure 2. As the prototype model has this single space type, the lighting power density, plug load, occupancy, ventilation rate, and their schedules are also uniform throughout the entire building.
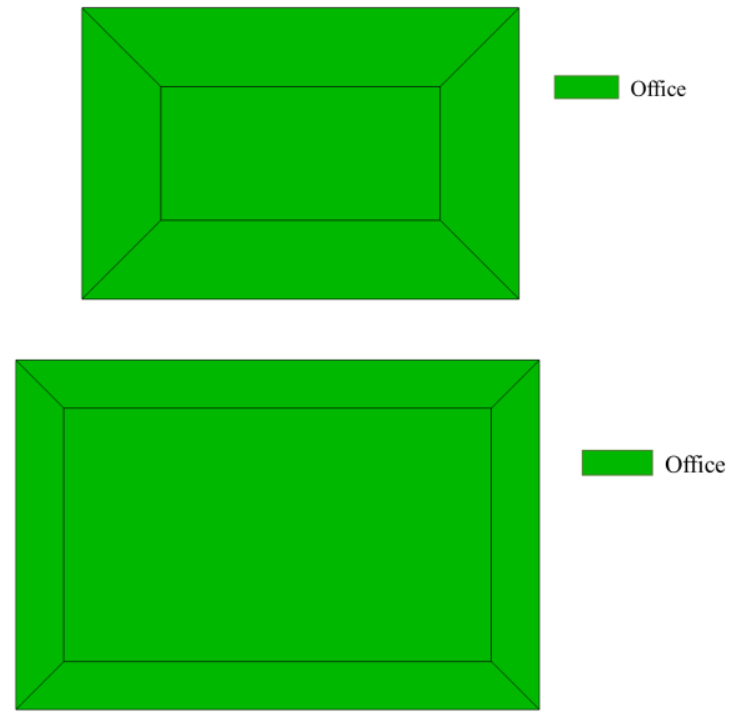

Figure 2: Original office prototype model layout-small office (top) and medium office (bottom).

\section{Update for Space Types}

The original small and medium office prototype was developed based on building characteristics found in National Commercial Construction Characteristics (NC3) database (Richman et al., 2008). Originally, the NC3 data set was developed to help provide answers to questions on current commercial design practices, which are important inputs to analyze regarding commercial building energy consumption. The data set is populated with over 130 possible building characteristics for 340 buildings from across the United States. The building characteristics were extracted from sets of real building plans and specifications acquired from the F.W. DODGE Plans Service Division of McGraw Hill. These represent buildings that were in the bid process during the summer of 2001 through the spring of 2007.

Table 1 shows the detailed space type and area fraction for the small and medium office prototype models, which was originally developed by PNNL based on the data from NC3. The updated OS small and medium office prototype building model follows the space types and their \% space areas defined in Table 1 . Once space types are assigned for the corresponding space area, typical small and medium office building plans (Chiara et al., 2001; GSA, 2019; GSA, 2012) were reviewed to define the new space allocations to the original office model. In case of medium office model, assigning the spaces to each floor, the following were considered to assign the spaces to each floor:
1. All spaces are allocated in the same manner for mid and top floors

2. The core zone space is the same for all floors. For the perimeter zone, the bottom floor has a lounge and classroom. Due to the presence of additional spaces for the bottom floor, the open and enclosed office spaces were reorganized accordingly.

In this new small and medium office prototype model, building envelope (i.e., wall, roof, and windows) thermal properties and HVAC system type remain the same with the original medium office prototype building models. The HVAC system capacity will be auto-sized and therefore may be different from the original model. Given one VAV box for each space, the total number of VAV boxes has increased in the new model. The number of AirLoopHVAC (i.e., AHU) remains the same: one for each floor.

Table 1: Space types and area fractions for major zones of the updated small and medium office.

\begin{tabular}{|c|c|c|}
\hline \multirow[t]{2}{*}{ Space } & \multicolumn{2}{|c|}{ Area Fraction } \\
\hline & $\begin{array}{l}\text { Small Office } \\
\left(511.0 \mathrm{~m}^{2}\right)\end{array}$ & $\begin{array}{c}\text { Medium Office } \\
\left(4,979.6 \mathrm{~m}^{2}\right)\end{array}$ \\
\hline Office - open plan & $15 \%$ & $42.40 \%$ \\
\hline Office - enclosed & $29 \%$ & $18.70 \%$ \\
\hline Corridor/Transition & $12 \%$ & $9.10 \%$ \\
\hline $\begin{array}{l}\text { Conference Meeting/ } \\
\text { Multipurpose }\end{array}$ & $8 \%$ & $5.20 \%$ \\
\hline Stairway & $3 \%$ & $3.70 \%$ \\
\hline Lobby & $6 \%$ & $3.70 \%$ \\
\hline Restrooms & $4 \%$ & $3.60 \%$ \\
\hline Electrical/Mechanical & $2 \%$ & $3.00 \%$ \\
\hline $\begin{array}{l}\text { Active storage }<50 \& \\
>1000 \mathrm{ft}^{2}\end{array}$ & \multirow[t]{2}{*}{$14 \%$} & $5.20 \%$ \\
\hline Active storage $50-1000 \mathrm{ft}^{2}$ & & $1.90 \%$ \\
\hline Lounge/Recreation & $2 \%$ & $1.80 \%$ \\
\hline Dining Area & - & $0.90 \%$ \\
\hline Classroom/Lecture/Training & - & $0.60 \%$ \\
\hline Food Preparation $^{1}$ & - & $0.40 \%$ \\
\hline
\end{tabular}

${ }^{1}$ Combined with dining area

The number of occupants, plug load density $\left(\mathrm{W} / \mathrm{m}^{2}\right)$, lighting power density $\left(\mathrm{W} / \mathrm{m}^{2}\right)$, and ventilation load are varied based on the space type as defined in ASHRAE Standard 90.1 and 62.1. However, the schedules for occupancy, lighting power, and plug loads remain the same with the original model.

Figure 3-4 illustrate the new prototype floor layout for ground floor, and mid/top floors, respectively. Figure 5 shows the $3 \mathrm{D}$ rendering of the new prototype office building models.

Once all the building characteristics for the prototype small and medium office buildings were defined, the prototype building model was generated in automated way. An OpenStudio Measure was used to automatically generate the small and medium office prototype building 
for 16 climate locations and 4 building standards (Roth et al., 2016). This measure, OpenStudio-Standards, provides mechanisms to add new building types, and its building characteristics. Additionally, the measure automatically assigns and models all 90.1 building standard requirements. By using an OpenStudio Measure, the OpenStudio-Standards can be used to generate OpenStudio Prototype Buildings using all OpenStudio workflows.
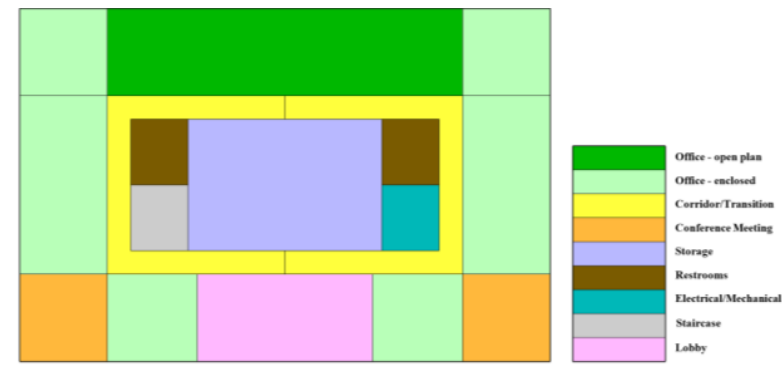

Figure 3: New small office prototype model layout.
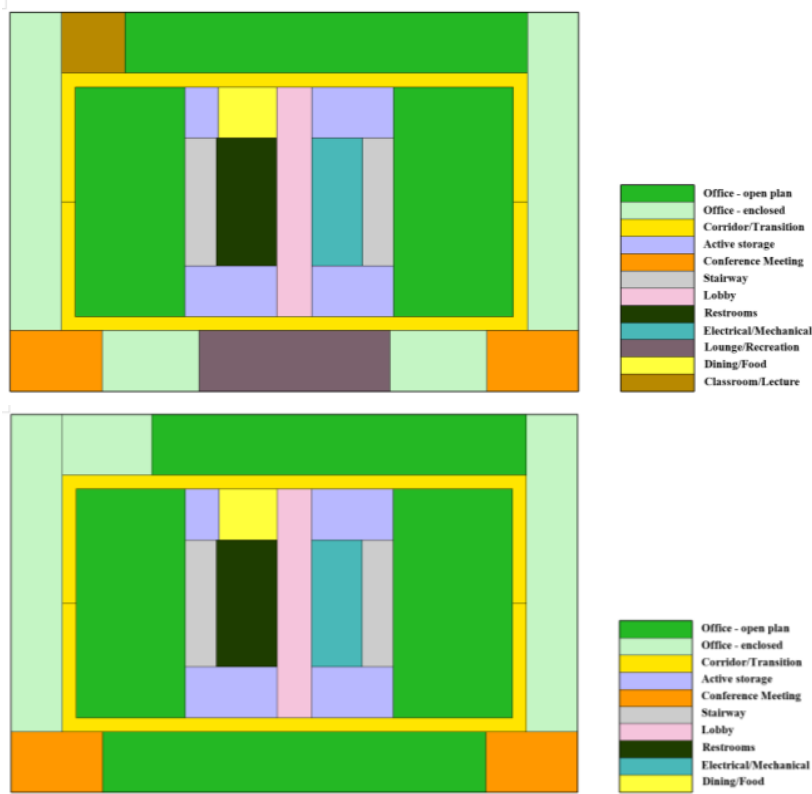

Figure 4: New medium office prototype model layoutground floor (top), mid and top floors (bottom).

\section{Results}

\section{Input Comparison}

Tables 2 to 5 compare the input values for the original prototype models and the updated models for different vintages of the ASHRAE 90.1 standard. The variables include lighting power, ventilation rate, occupancy, and electrical equipment power per area. As previously mentioned, the original model has a single uniform space type, office, and there is only one input value per each category. The updated model has various space types, and each space type has different input values based on the definitions from the ASHRAE 90.1 and ASHRAE 62.1(ANSI/ASHRAE/IES, 2016).
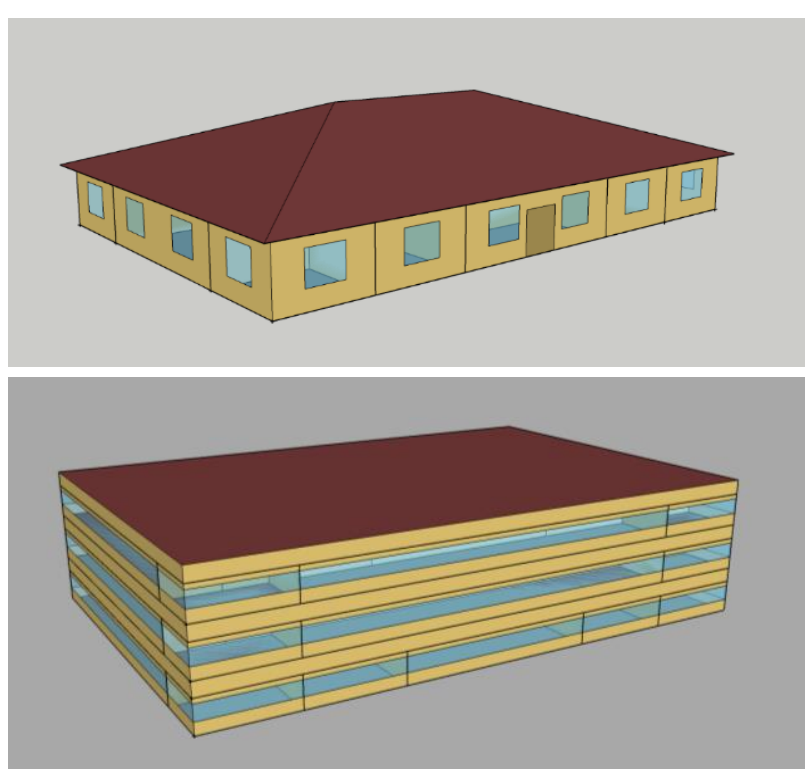

Figure 5: $3 D$ rendering of the new small (top) and medium (bottom) office prototype building models. (bottom) office prototype building models.

The last four rows of each table show the area/occupancy weighted average input value for the new prototype building model and percentage increase compared to the original model. It appears, in general, the average input value for the new model is comparable with the original single input value with less than $10 \%$ differences The lighting power is slightly increased whereas the plug load is decreased for all vintages. As a result, it is expected that the effects of lighting and plug load on total building energy consumption is compensated. The ventilation rate introduced to the building is slightly increased (10\% $29 \%$ ) except for the ventilation rate for 2004 vintage (new $0.91 \mathrm{~L} / \mathrm{s}-\mathrm{m}^{2}$ vs. original $0.51 \mathrm{~L} / \mathrm{s}-\mathrm{m}^{2}$ ) for medium office model, new $1.07 \mathrm{~L} / \mathrm{s}-\mathrm{m}^{2}$ vs. original $0.51 \mathrm{~L} / \mathrm{s}-\mathrm{m}^{2}$ for small office model). Due to largely increased ventilation rate in this vintage, it is expected there would be increased cooling and heating energy use, and this is discussed further in next section - output comparison.

\section{Output Comparison}

Table 6 and Figure 6 compare the annual total energy use for the original OS small and medium office building and the newly developed OS small and medium office buildings for the selected climate zones and ASHRAE 90.1 standard vintages. The selected regions to compare the results are ASHRAE US climate zone 2A, 3B, 4A, 5A, and $6 \mathrm{~A}$. Given the changes in the occupancy density, lighting and plug load, and OA ventilation rates in the new prototype building model, the energy uses for two different models show close agreement. In general, the energy use for the new model is slightly higher than the original. 
Table 2: Lighting, ventilation, occupancy, and elec. equipment per area for ASHRAE 90.1-2004.

\begin{tabular}{|c|c|c|c|c|c|c|}
\hline Prototype & Space Type & \begin{tabular}{|c|} 
Lighting \\
per Area \\
$\left(\mathbf{W} / \mathbf{m}^{2}\right)$
\end{tabular} & \begin{tabular}{|c|} 
Ventilatio \\
n per \\
Area \\
$\left(\mathrm{L} / \mathbf{s}^{*} \mathrm{~m}^{2}\right)$ \\
\end{tabular} & $\begin{array}{c}\text { Ventilation } \\
\text { per Person } \\
\left(\mathrm{L} / \mathrm{s}^{*} \text { person) }\right.\end{array}$ & $\begin{array}{c}\text { Occupancy } \\
\text { per Area } \\
(\text { people/m²) }\end{array}$ & \begin{tabular}{|c|} 
Electric \\
Equipmen \\
t per Area \\
$\left(\mathrm{W} / \mathrm{m}^{2}\right)$ \\
\end{tabular} \\
\hline Original & $\begin{array}{l}\text { WholeBuilding - Md } \\
\text { Office }\end{array}$ & 10.76 & 0.51 & & 0.05 & 8.07 \\
\hline Original & $\begin{array}{l}\text { WholeBuilding - Small } \\
\text { Office }\end{array}$ & 10.76 & 0.51 & & 0.06 & 6.78 \\
\hline \multirow{15}{*}{ Updated } & Storage & 8.61 & 0.76 & & & \\
\hline & Stair & 6.46 & 0.25 & & & \\
\hline & Restroom & 9.69 & 0.25 & & & 2.91 \\
\hline & OpenOffice & 11.84 & 0.00 & 9.44 & 0.06 & 10.33 \\
\hline & Lobby $^{3}$ & 13.99 & 0.00 & 7.08 & 0.11 & 2.91 \\
\hline & Elec/MechRoom & 16.15 & 0.76 & & & 2.91 \\
\hline & Corridor & 5.38 & 0.25 & & & 3.12 \\
\hline & \begin{tabular}{|l|} 
Conference \\
\end{tabular} & 13.99 & 0.00 & 9.44 & 0.54 & 10.76 \\
\hline & \begin{tabular}{|l|} 
ClosedOffice \\
\end{tabular} & 11.84 & 0.00 & 9.44 & 0.05 & 9.36 \\
\hline & \begin{tabular}{|l|} 
Dining \\
\end{tabular} & 9.69 & 0.00 & 7.08 & 0.11 & 10.76 \\
\hline & \begin{tabular}{|l|} 
Classroom \\
\end{tabular} & 15.07 & 0.00 & 8.00 & 0.38 & 10.00 \\
\hline & $\begin{array}{l}\text { Weighted Average - Md } \\
\text { Office }\end{array}$ & 11.09 & 0.91 & & 0.07 & 7.6 \\
\hline & $\begin{array}{l}\text { Weighted Average - } \\
\text { Small Office }\end{array}$ & 10.87 & 1.07 & & 0.08 & 6.46 \\
\hline & $\begin{array}{l}\text { Percentage Increase- Md } \\
\text { Office [\%] }\end{array}$ & 3 & 80 & & 33 & -5 \\
\hline & $\begin{array}{l}\text { Percentage Increase- Sm } \\
\text { Office [\%] }\end{array}$ & 1 & 110 & & 31 & \\
\hline
\end{tabular}

Table 3: Lighting, ventilation, occupancy, and elec. equipment per area for ASHRAE 90.1-2007.

\begin{tabular}{|c|c|c|c|c|c|c|}
\hline Prototype & Space Type & $\begin{array}{c}\text { Lighting } \\
\text { per Area } \\
\left(\mathrm{W} / \mathbf{m}^{2}\right)\end{array}$ & \begin{tabular}{|c|} 
Ventilatio \\
n per \\
Area \\
$\left(\mathrm{L} / \mathrm{s}^{*} \mathrm{~m}^{2}\right)$ \\
\end{tabular} & $\begin{array}{c}\text { Ventilation } \\
\text { per Person } \\
\left(\mathrm{L} / \mathrm{s}^{*} \text { person) }\right.\end{array}$ & 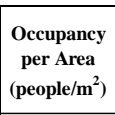 & $\begin{array}{c}\text { Electric } \\
\text { Equipmen } \\
\text { t per Area } \\
\left(\mathrm{W} / \mathrm{m}^{2}\right) \\
\end{array}$ \\
\hline Original & $\begin{array}{l}\text { WholeBuilding - Md } \\
\text { Office }\end{array}$ & 10.76 & 0.46 & & 0.05 & 8.07 \\
\hline Original & $\begin{array}{l}\text { WholeBuilding - Sm } \\
\text { Office }\end{array}$ & 10.76 & 0.51 & & 0.06 & 6.78 \\
\hline \multirow{15}{*}{ Updated } & Storage & 8.61 & 0.61 & & & \\
\hline & Stair & 6.46 & 0.30 & & . & \\
\hline & Restroom & 9.69 & 0.30 & & & 2.91 \\
\hline & OpenOffice & 11.84 & 0.30 & 2.36 & 0.06 & 10.33 \\
\hline & Lobby & 13.99 & 0.30 & 2.36 & 0.11 & 2.91 \\
\hline & Elec/MechRoom & 16.15 & 0.61 & & & 2.91 \\
\hline & Corridor & 5.38 & 0.30 & & & 3.12 \\
\hline & \begin{tabular}{|l|} 
Conference \\
\end{tabular} & 13.99 & 0.30 & 2.36 & 0.54 & 10.76 \\
\hline & \begin{tabular}{|l|} 
ClosedOffice \\
\end{tabular} & 11.84 & 0.30 & 2.36 & 0.05 & 9.36 \\
\hline & \begin{tabular}{|l|} 
Dining \\
\end{tabular} & 9.69 & 0.30 & 2.36 & 0.11 & 10.76 \\
\hline & \begin{tabular}{|l|} 
Classroom \\
\end{tabular} & 15.07 & 0.61 & 4.72 & 0.38 & 10.00 \\
\hline & $\begin{array}{l}\text { Weighted Average - Md } \\
\text { Office }\end{array}$ & 11.09 & 0.51 & & 0.07 & 7.64 \\
\hline & $\begin{array}{l}\text { Weighted Average - } \\
\text { Small Office }\end{array}$ & 10.87 & 0.56 & & 0.08 & 6.46 \\
\hline & $\begin{array}{l}\text { Percentage Increase- Md } \\
\text { Office [\%] }\end{array}$ & 3 & 11 & & 33 & -5 \\
\hline & $\begin{array}{l}\text { Percentage Increase- Sm } \\
\text { Office [\%] }\end{array}$ & 1 & 10 & & 31 & -5 \\
\hline
\end{tabular}

Table 4: Lighting, ventilation, occupancy, and elec. equipment per area for ASHRAE 90.1-2010.

\begin{tabular}{|c|c|c|c|c|c|c|}
\hline Prototype & Space Type & \begin{tabular}{|c|}
$\begin{array}{c}\text { Lighting } \\
\text { per Area } \\
\left(\mathrm{W} / \mathbf{m}^{2}\right)\end{array}$ \\
\end{tabular} & \begin{tabular}{|c|} 
Ventilatio \\
n per \\
Area \\
$\left(\mathrm{L} / \mathbf{s}^{*} \mathrm{~m}^{2}\right)$ \\
\end{tabular} & $\begin{array}{c}\text { Ventilation } \\
\text { per Person } \\
\left(\mathrm{L} / \mathrm{s}^{*} \text { person) }\right.\end{array}$ & $\begin{array}{c}\text { Occupancy } \\
\text { per Area } \\
(\text { people/m }\end{array}$ & $\begin{array}{c}\text { Electric } \\
\text { Equipmen } \\
\text { t per Area } \\
\left(\mathrm{W} / \mathbf{m}^{2}\right) \\
\end{array}$ \\
\hline Original & $\begin{array}{l}\text { WholeBuilding - Md } \\
\text { Office }\end{array}$ & 9.69 & 0.46 & & 0.05 & 8.07 \\
\hline Original & $\begin{array}{l}\text { WholeBuilding - Sm } \\
\text { Office }\end{array}$ & 9.69 & 0.43 & & 0.06 & 6.78 \\
\hline \multirow{15}{*}{ Updated } & Storage & 6.78 & 0.61 & & & \\
\hline & Stair & 7.43 & 0.30 & & - & \\
\hline & Restroom & 10.55 & 0.30 & & & 2.91 \\
\hline & \begin{tabular}{|l} 
OpenOffice \\
\end{tabular} & 10.55 & 0.30 & 2.36 & 0.06 & 10.33 \\
\hline & Lobby & 9.69 & 0.30 & 2.36 & 0.11 & 2.91 \\
\hline & Elec/MechRoom & 10.23 & 0.61 & & - & 2.91 \\
\hline & Corridor & 7.10 & 0.30 & & - & 3.12 \\
\hline & Conference & 13.24 & 0.30 & 2.36 & 0.54 & 10.76 \\
\hline & \begin{tabular}{|l|} 
ClosedOffice \\
\end{tabular} & 11.95 & 0.30 & 2.36 & 0.05 & 9.36 \\
\hline & Dining & 7.00 & 0.30 & 2.36 & 0.11 & 10.76 \\
\hline & Classroom & 13.35 & 0.61 & 4.72 & 0.38 & 10.00 \\
\hline & $\begin{array}{l}\text { Weighted Average - Md } \\
\text { Office }\end{array}$ & 10.23 & 0.51 & & 0.07 & 7.64 \\
\hline & $\begin{array}{l}\text { Weighted Average - } \\
\text { Small Office }\end{array}$ & 10.12 & 0.56 & & 0.08 & 6.46 \\
\hline & $\begin{array}{l}\text { Percentage Increase- Md } \\
\text { Office [\%] }\end{array}$ & 6 & 11 & & 33 & -5 \\
\hline & $\begin{array}{l}\text { Percentage Increase- Sm } \\
\text { Office [\%] }\end{array}$ & 4 & 29 & & 31 & -5 \\
\hline
\end{tabular}

Table 5: Lighting, ventilation, occupancy, and elec. equipment per area for ASHRAE 90.1-2013.

\begin{tabular}{|c|c|c|c|c|c|c|}
\hline Prototype & Space Type & $\begin{array}{c}\text { Lighting } \\
\text { per Area } \\
\left(\mathrm{W} / \mathrm{m}^{2}\right)\end{array}$ & $\begin{array}{c}\text { Ventilatio } \\
\text { n per } \\
\text { Area } \\
\left(\mathrm{L} / \mathrm{s}^{*} \mathrm{~m}^{2}\right) \\
\end{array}$ & $\begin{array}{c}\text { Ventilation } \\
\text { per Person } \\
\text { (L/s*person) }\end{array}$ & $\begin{array}{c}\text { Occupancy } \\
\text { per Area } \\
\left(\text { people } / \mathbf{m}^{2}\right)\end{array}$ & \begin{tabular}{|c|} 
Electric \\
Equipmen \\
t per Area \\
$\left(\mathrm{W} / \mathrm{m}^{2}\right)$ \\
\end{tabular} \\
\hline Original & $\begin{array}{l}\text { WholeBuilding - Sm } \\
\text { Office }\end{array}$ & 8.83 & 0.43 & & 0.06 & 6.78 \\
\hline Original & $\begin{array}{l}\text { WholeBuilding - Md } \\
\text { Office }\end{array}$ & 8.83 & 0.46 & & 0.05 & 8.07 \\
\hline \multirow{15}{*}{ Updated } & Storage & 6.78 & 0.61 & & & \\
\hline & Stair & 7.43 & 0.30 & & & \\
\hline & Restroom & 10.55 & 0.30 & & & 2.91 \\
\hline & \begin{tabular}{|l|} 
OpenOffice \\
\end{tabular} & 10.55 & 0.30 & 2.36 & 0.06 & 10.33 \\
\hline & Lobby & 9.69 & 0.30 & 2.36 & 0.11 & 2.91 \\
\hline & Elec/MechRoom & 4.52 & 0.61 & & & 2.91 \\
\hline & Corridor & 7.10 & 0.30 & 7 & & 3.12 \\
\hline & \begin{tabular}{|l|} 
Conference \\
\end{tabular} & 13.24 & 0.30 & 2.36 & 0.54 & 10.76 \\
\hline & ClosedOffice & 11.95 & 0.30 & 2.36 & 0.05 & 9.36 \\
\hline & Dining & 7.00 & 0.30 & 2.36 & 0.11 & 10.76 \\
\hline & Classroom & 13.35 & 0.61 & 4.72 & 0.38 & 10.00 \\
\hline & $\begin{array}{l}\text { Weighted Average - Md } \\
\text { Office }\end{array}$ & 10.01 & 0.51 & & 0.07 & 7.64 \\
\hline & $\begin{array}{l}\text { Weighted Average - } \\
\text { Small Office }\end{array}$ & 10.01 & 0.56 & & 0.08 & 6.46 \\
\hline & $\begin{array}{l}\text { Percentage Increase- Md } \\
\text { Office [\%] }\end{array}$ & 13 & 18 & & 19 & 13 \\
\hline & $\begin{array}{l}\text { Percentage Increase- Sm } \\
\text { Office [\%] }\end{array}$ & 13 & 22 & & 47 & -20 \\
\hline
\end{tabular}

As discussed previously, the new models for ASHRAE 90.1-2004 show higher energy use than the original model in case of small and medium office building. This is mainly caused by increased OA ventilation loads compared to the original model. The increased ventilation loads results in increased heating and cooling energy use and the results shows a trend of regional impact. The percent difference between the two models ranges from 5$20 \%$ (5-10\% if the 2004 vintage outlier is excluded) for medium office buildings, and 0 to $10 \%$ for small office buildings $(0-8 \%$ if the 2004 vintage outlier is excluded) and this difference is somewhat significant in cold and hot climate such as $2 \mathrm{~A}$ and $6 \mathrm{~A}$ in general.

\section{Discussion}

In this new prototype model development, there was no attempt to match the energy use for the new prototype building models to the energy use of the original building models. Since the new model has more space types and associated space attributes, the energy use for the new model should be expected to be different. However, we perform an energy use comparison analysis between the new and original prototype building models to ensure reasonable trends and patterns in comparing the small and medium office across climate zones and for different vintages (i.e., 2004, 2007, 2010, and 2013) of the ASHRAE 90.1 standard.

Current discrepancies in energy use are mainly due to more space types and space specific lighting, plug power densities, ventilation rates. In addition, the number of HVAC system units and VAV boxes are increased (and individual system capacities were reduced) as more number of thermal zones were modelled, which would impact to the cooling and heating end energy use.

This paper is mainly focused on U.S. typical office buildings as the main objective of this work is to update the current U.S. office prototype building models with various space types, so that users can have more 
flexibility in modeling in many use cases. However, authors believe that the same methodology can be similarly applied to other countries to develop a new prototype office building models with their own energy code.

Table 6: Annual energy use comparison between the original and new OS prototype small office building (top) and medium office building (bottom).

\begin{tabular}{|c|c|c|c|c|}
\hline Template & Climate Zone & $\begin{array}{l}\text { Original OS Prototype Model } \\
\text { Total Annual Energy Use } \\
\text { (GJ) }\end{array}$ & $\begin{array}{l}\text { New OS Prototype Model } \\
\text { Total Annual Energy Use } \\
\text { (GJ) }\end{array}$ & $\begin{array}{l}\text { Percent Differences } \\
\text { (\%) }\end{array}$ \\
\hline \multirow[t]{5}{*}{$90.1-2004$} & $2 \mathrm{~A}$ & 238.35 & 241.9 & $1 \%$ \\
\hline & $3 B$ & 230.88 & 233.86 & $1 \%$ \\
\hline & $4 \mathrm{~A}$ & 237 & 251.42 & $6 \%$ \\
\hline & $5 \mathrm{~A}$ & 257.55 & 279.74 & $9 \%$ \\
\hline & $6 \mathrm{~A}$ & 264.45 & 291.52 & $10 \%$ \\
\hline \multirow[t]{5}{*}{$90.1-2007$} & $2 \mathrm{~A}$ & 229.6 & 229.2 & $0 \%$ \\
\hline & $3 B$ & 221.74 & 222.33 & $0 \%$ \\
\hline & $4 \mathrm{~A}$ & 229.88 & 234.44 & $2 \%$ \\
\hline & $5 A$ & 244.06 & 250.93 & $3 \%$ \\
\hline & $6 \mathrm{~A}$ & 249.86 & 256.76 & $3 \%$ \\
\hline \multirow[t]{5}{*}{$90.1-2010$} & $2 \mathrm{~A}$ & 205.29 & 209.37 & $2 \%$ \\
\hline & $3 B$ & 199.22 & 203.59 & $2 \%$ \\
\hline & $4 \mathrm{~A}$ & 205 & 213.52 & $4 \%$ \\
\hline & $5 \mathrm{~A}$ & 217.68 & 229.47 & $5 \%$ \\
\hline & $6 \mathrm{~A}$ & 222.55 & 235.35 & $6 \%$ \\
\hline \multirow[t]{5}{*}{$90.1-2013$} & $2 \mathrm{~A}$ & 174.17 & 177.66 & $2 \%$ \\
\hline & $3 B$ & 170.51 & 174.54 & $2 \%$ \\
\hline & 4A & 174.55 & 184.13 & $5 \%$ \\
\hline & $5 \mathrm{~A}$ & 187.03 & 200.41 & $7 \%$ \\
\hline & $6 \mathrm{AA}$ & 194.01 & 209.08 & $8 \%$ \\
\hline
\end{tabular}

\begin{tabular}{|c|c|c|c|c|}
\hline Template & \begin{tabular}{|l|} 
Climate Zone \\
\end{tabular} & $\begin{array}{l}\text { Original OS Prototype Model } \\
\text { Total Annual Energy Use } \\
\text { (GJ) }\end{array}$ & $\begin{array}{l}\text { New OS Prototype Model } \\
\text { Total Annual Energy Use } \\
\text { (GJ) }\end{array}$ & $\begin{array}{l}\text { Percent Differences } \\
(\%)\end{array}$ \\
\hline \multirow[t]{5}{*}{$90.1-2004$} & $2 \mathrm{~A}$ & 2,889 & 3,375 & $17 \%$ \\
\hline & $3 B$ & 2,526 & 2,844 & $13 \%$ \\
\hline & $4 \mathrm{~A}$ & 2,849 & 3,345 & $17 \%$ \\
\hline & $5 \mathrm{~A}$ & 3,138 & 3,741 & $19 \%$ \\
\hline & $6 \mathrm{~A}$ & 3,211 & 3,862 & $20 \%$ \\
\hline \multirow[t]{5}{*}{ 90.1-2007 } & $2 \mathrm{~A}$ & 2,768 & 2,987 & $8 \%$ \\
\hline & 3B & 2,403 & 2,557 & $6 \%$ \\
\hline & $4 \mathrm{~A}$ & 2,634 & 2,814 & $7 \%$ \\
\hline & $5 \mathrm{~A}$ & 2,882 & 3,079 & $7 \%$ \\
\hline & $6 \mathrm{~A}$ & 2,928 & 3,130 & $7 \%$ \\
\hline \multirow[t]{5}{*}{$90.1-2010$} & $2 \mathrm{~A}$ & 2,229 & 2,442 & $10 \%$ \\
\hline & $3 B$ & 1,915 & 2,022 & $6 \%$ \\
\hline & $4 \mathrm{~A}$ & 2,021 & 2,162 & $7 \%$ \\
\hline & $5 \mathrm{~A}$ & 2,215 & 2,382 & $8 \%$ \\
\hline & $6 \mathrm{~A}$ & 2,238 & 2,416 & $8 \%$ \\
\hline \multirow[t]{5}{*}{ 90.1-2013 } & $2 \mathrm{~A}$ & 1,891 & 2,062 & $9 \%$ \\
\hline & $3 B$ & 1,753 & 1,843 & $5 \%$ \\
\hline & $4 \mathrm{~A}$ & 1,861 & 1,993 & $7 \%$ \\
\hline & $5 \mathrm{~A}$ & 2,033 & 2,192 & $8 \%$ \\
\hline & $6 \mathrm{~A}$ & 2,049 & 2,226 & $9 \%$ \\
\hline
\end{tabular}

\section{Conclusion}

This paper discussed the updated the small and medium office prototype models with inclusion of new space types based on definitions in existing standards. Given the different space types and layout, the simulated energy use for the updated models show relatively close agreements with the use of the original office models except ASHRAE 90.1-2004 version. With the updated large office model (not discussed in this paper), all three office models with detailed spaces types will be provided in OpenStudio as measures, which will be compatible with all future versions of EnergyPlus as well. The updated models are expected to provide more flexibility in modeling occupancy behaviour per space types, and detailed analysis of retrofit solutions, HVAC system design and operation, as well as grid demand response study.

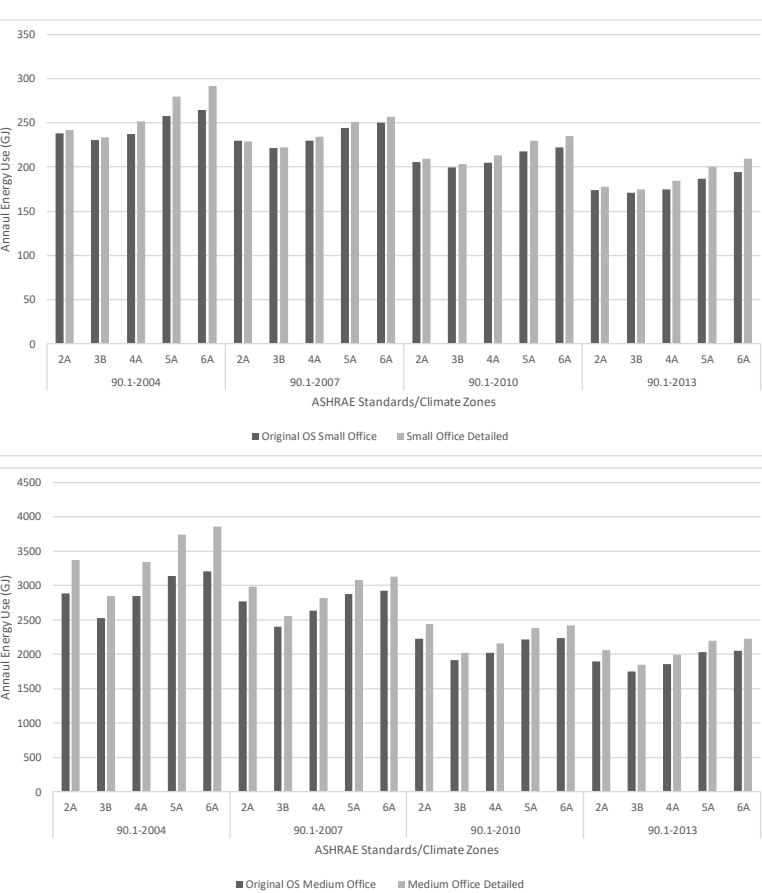

Figure 6: Annual energy use comparison between the original and new OS prototype small office building (top) and medium office building (bottom).

\section{Acknowledgement}

This material is based upon work supported by the U.S. Department of Energy, Office of Science, and Building Technologies Office. This research used resources of the Oak Ridge National Laboratory Building Technologies Research and Integration (BTRIC), which is a DOE Office of Science User Facility. This work was funded by field work proposal CEBT105 under DOE Building Technology Office Activity Numbers BT0302000 and BT0305000. This manuscript has been authored by UTBattelle, LLC, under Contract Number DEAC0500OR22725 with DOE. The United States Government retains and the publisher, by accepting the article for publication, acknowledges that the United States Government retains a non-exclusive, paid-up,

irrevocable, world-wide license to publish or reproduce the published form of this manuscript, or allow others to do so, for United States Government purposes.

\section{References}

ANSI/ASHRAE/IES Standard 62.1-2016 (2016). "Ventilation for Acceptable Indoor Air Quality" Goel, S., Athalye, R., Wang, W., Zhang J., Rosenberg, M., Xie, Y., Hart, R., Mendon, V. 2014. "Enhancements to ASHRAE Standard 90.1 Prototype Building Models," PNNL-23269. Available WWW: https://www.energycodes.gov/sites/default/files/docu ments/PrototypeModelEnhancements_2014_0.pdf

ANSI/ASHRAE/IES Standard 90.1-2016 (2016). Energy Standard for Buildings Except Low-Rise Residential Buildings." Available WWW: 
https://www.ashrae.org/resources--

publications/bookstore/standard-90-1.

Building Energy Codes Programs (2019) Retrieved from https://www.energycodes.gov/development/commerc ial/prototype_models

Chiara, J., and M. Crosbie (2001). Time-Saver Standards For Building Types, Fourth Edition, McGraw-Hill, New York, NY.

Deru, M., Field K., Studer, D., Benne, K., Griffith, B., Tocellini, P., Liu, B., Halverson, M., Winiarski, D., Yazdanian, M., Huang, J., and Crawley, D. (2011). "U.S. Department of Energy Commercial Reference Building Models of the National Building Stock," NREL/TP-5500-46861. Available WWW: http://www.nrel.gov/docs/fy11osti/46861.pdf

Goel, S., Athalye, R., Wang, W., Zhang J., Rosenberg, M., Xie, Y., Hart, R., Mendon, V. (2014). "Enhancements to ASHRAE Standard 90.1 Prototype Building Models," PNNL-23269. Available WWW: https://www.energycodes.gov/sites/default/files/docu ments/PrototypeModelEnhancements_2014_0.pdf

GSA (2012) Circulation: Defining and Planning, Retrieved
https://www.gsa.gov/cdnstatic/Circulation__Defining_and_Planning_\%28May_2012\%29.pdf

GSA (2019) GSA Unit Cost Study, Retrieved from https://www.wbdg.org/FFC/GSA/gsa_usc_shell_offi ce.pdf

International Code Council (2015). 2015 International Energy Conservation Code (IECC)." Available WWW: http://codes.iccsafe.org/app/book/toc/2015/ICodes/2015\%20IECC\%20HTML/index.html

PNNL (2013). "Commercial Prototype Building Models." Available WWW: https://www.energycodes.gov/development/commerc ial/prototype_models

Richman, E., Rauch, E., Phillips, J., Petty, K., Knappek J., Lopez-Rangel P. (2008). "National Commercial Construction Characteristics and Compliance with Building Energy Codes: 1999-2007," 2008 ACEEE Summer Study on Energy Efficiency in Buildings, pp. 291-306. Available WWW: http://aceee.org/files/proceedings/2008/data/papers/3 -250.pdf 